\title{
GENETIC DIVERGENCE IN PEPPER GENOTYPES FROM SOUTHWEST GOIÁS
}

\section{Divergência genética entre genótipos de pimenta coletados no sudoeste goiano}

\author{
Renata Cristina Alvares ${ }^{1}$, Edésio Fialho dos Reis² ${ }^{2}$ Jefferson Fernando Naves Pinto ${ }^{3}$
}

\begin{abstract}
Knowledge on the genetic diversity in genebanks is important for germplasm conservation and use in breeding programs, where it can reduce time and costs of breeding of new genotypes. The purpose of this study was to evaluate the genetic divergence among 137 genotypes of Capsicum chinense Jacq. by morphological descriptors and multivariate techniques, with a view to the identification of groups for promising crosses for breeding programs. The experiment was conducted in a greenhouse, arranged in a randomized complete block design with four replications, where each plot consisted of a pot with one plant. The 20 descriptors recommended by the International Plant Genetic Resources Institute - IPGRI were considered for the morphological characterization. By analysis of variance, significant differences between genotypes were detected for the studied descriptors. Clustering by the Tocher optimization method formed five groups, and by the hierarchical clustering method UPGMA, 11 groups. Based on larger distances intergroup, crosses are recommended among genotypes of the groups II x V, II x IV, and I x V for the Tocher method, and by UPGMA among genotypes of the groups VI x XI, II x XI, IV x XI,. The cophenetic correlation coefficient for the hierarchical clustering method UPGMA was 0.797 (p $<0.01)$. The traits that contributed most to the total genetic diversity were number of days to flowering and plant height.
\end{abstract}

Index terms: Capsicum chinense Jacq., morphological evaluation, multivariate techniques, plant breeding.

\section{RESUMO}

O conhecimento da divergência genética em coleções de germoplasma é importante para fins de conservação e uso em programas de melhoramento genético, reduzindo tempo e custo na obtenção de novos genótipos. Neste trabalho, objetivou-se avaliar a divergência genética entre 137 genótipos de Capsicum chinense Jacq., por meio de descritores morfológicos, empregando-se técnicas multivariadas, para a identificação de grupos de intercruzamentos com potencial uso em programas de melhoramento. O experimento foi conduzido em casa de vegetação, sendo os genótipos dispostos no delineamento de blocos completos casualizados, com quatro repetições, cada parcela constituída de um vaso com uma planta. Para a caracterização morfológica foram considerados vinte descritores entre os recomendados pelo International Plant Genetic Resources Institute - IPGRI. Pela análise de variância, evidenciaramse diferenças significativas entre os genótipos para os descritores estudados. O método de otimização de Tocher detectou a formação de cinco grupos e, o método de agrupamento hierárquico UPGMA, a formação de 11 grupos. Com base nas maiores distâncias intergrupos, recomenda-se cruzamentos, pelo método de otimização de Tocher, entre genótipos dos grupos II com V, II com IV, I com V, e, pelo método hierárquico UPGMA, entre genótipos dos grupos VI com XI, II com XI, IV com XI. O coeficiente de correlação cofenético para o agrupamento hierárquico UPGMA foi de $0,797(\mathrm{p}<0,01)$. Os descritores que mais contribuíram para a divergência genética total foram número de dias para florescimento e altura de plantas.

Termos para indexação: Capsicum chinense Jacq., avaliação morfológica, técnicas multivariadas, melhoramento de plantas.

(Received in july 6, 2012 and approved in august 20, 2012)

\section{INTRODUCTION}

Brazil is an important center of diversity of the genus Capsicum spp, where domesticated as well as semidomesticated and wild species are found (CARVALHO et al., 2003), allowing the exploration of this variability in breeding programs. According to Carvalho and Bianchetti (2008), the domesticated species in Brazil are $C$. annuum L. var. annuum, C. baccatum var. pendulum (Wild) Eshbaugh, C. frutescens L., and $C$. chinense Jacq.
The species $C$. chinense Jacq. is noteworthy for being considered the most Brazilian of the domesticated species, since the Amazon is its largest center of genetic diversity (CARVALHO; BIANCHETTI, 2008). According to Reifschneider (2000), the species is also found in the Midwest and Northeastern regions of Brazil. It comprises morphotypes known as pimenta de cheiro, pimenta bode, cumari do Pará, murupi, habanero, and biquinho. Also, according to Reifschneider (2000), in the states of midwestern Brazil, the most relevant morphotypes are pimenta bode and

\footnotetext{
'Universidade Federal de Goiás/UFG - Goiânia - GO - Brasil

${ }^{2}$ Universidade Federal de Goiás/UFG - Rod. BR 364 KM 194 - Setor Parque Industrial - 3800 - Cx. P. 03 - $75800-000$ - Jataí - GO - Brasil edesio7@brturbo.com.br

${ }^{3}$ Universidade Federal de Goiás/UFG - Jataí - GO - Brasil
}

Ciênc. agrotec., Lavras, v. 36, n. 5, p. 498-506, set./out., 2012 
pimenta de cheiro, widely used in cooking as a seasoning, aside from being sold as canned and preserved food. For being remarkably adaptable to tropical and equatorial climate conditions and due to its great genetic variability, particularly evident in the fruits that can have different shapes, colors, sizes, and pungency levels, Capsicum chinense is among the most produced and consumed peppers in Brazil (CARVALHO et al., 2003; LANNES et al., 2007).

In view of the economic importance of the species, it is appropriate to study the genetic divergence as a useful and effective tool of separation of accessions in genebanks (REGO et al., 2003), as well as for the identification of suitable parents for hybrids with higher heterotic effect (CRUZ; CARNEIRO, 2006). For the species Capsicum chinense Jacq., significant heterosis has been found, making breeding for commercial exploitation viable (SOUSA; MALUF, 2000).

The success in breeding programs depends on divergent and promising plant material. To generate segregating populations for selection, the genetic complementation of the parents must be good, so the clustering techniques can assist in guiding the parent choice. In this sense, Benin et al. (2002) mentioned that genotypes in more distant clusters are possibly dissimilar, and can be considered promising for artificial crosses.

Few black pepper cultivars are available on the market, therefore, according to Bento et al. (2007), there is a great need for new cultivars that combine resistance to the major pepper pests and diseases with quality of taste and yield, especially to supply the agroindustry sector.

Within this context, numerous studies using multivariate analysis have been conducted to assess the genetic divergence, with the purpose of rationalizing breeding programs, by reducing the time required to develop promising accessions and consequently, spare costs. For the genus Capsicum, this technique was used by Sudré et al. (2005), Bento et al. (2007), Monteiro et al. (2010), Moura et al. (2010), among others.

The purpose of this study was to evaluate the genetic diversity of genotypes of the species Capsicum chinense Jacq., from the southwestern region of the State of Goiás, based on 20 descriptors, using multivariate analysis techniques to identify groups of promising intercrosses for pepper breeding programs.

\section{MATERIALS AND METHODS}

The experiment was conducted in Jataí, in the southwestern region of Goiás state (latitude $17^{\circ} 53^{\prime} \mathrm{S}$, longitude 51\%44'W, altitude $696 \mathrm{~m}$ asl) with a humid-tropical savanna, mesothermal climate, with rainy summers and dry winters, Awa according to the Köppen classification.
For the study, 137 genotypes of Capsicum chinense Jacq. were found on markets or donated by farmers in the southwestern region of Goiás State. At the time of sampling, about 20 mature fruits per plant were harvested for seed extraction. These were sown in polystyrene trays filled with commercial substrate, and left to grow in a greenhouse with anti-aphid mesh. Seedlings were transplanted 60 days after sowing to 8L plastic pots, filled with sifted soil and fertilized with yoorin Master ${ }^{\circledR}$, at a rate of $2 \mathrm{~g} \mathrm{~kg}^{-1}$ soil.

The experiment was arranged in a randomized complete block design with 137 treatments (genotypes) and four replications. Each experimental unit consisted of a pot with one plant. Phosphorus $(\mathrm{P})$ and potassium $(\mathrm{K})$ were applied monthly and sprays of insecticides and fungicides biweekly during cultivation, as recommended by Filgueira (2000). At this stage, drip irrigation was automatically applied every three hours. The entire experiment was conducted in a greenhouse.

For the morphological characterization, 20 descriptors, which are part of the set recommended by the International Plant Genetic Resources Institute - IPGRI (1995), were used: plant height, height of first bifurcation, fruit peduncle length, fruit length, corolla length, mature leaf length, canopy diameter, stem diameter, fruit wall thickness, fruit width, width of the fruit peduncle, mature leaf width, 10-fruit weight, number of seeds, number of locules, number of days to flowering, days to fruit set, number of branches, 100-seed weight, and seed size. All evaluations were performed as recommended by Ipgri (1995).

Univariate statistical analysis and significance by the F test were performed for the 20 descriptors. Multivariate analysis was used to study the genetic divergence. The genetic distance matrix was estimated by Mahalanobis' distance, as proposed by Cruz and Carneiro (2006), which was used as dissimilarity measure and applied for cluster analyses based on the Tocher optimization method described by Rao (1952) and the unweighted pair grouping method with arithmetic means (UPGMA), according to Sneath and Sokal (1973).

To evaluate the consistency of the dendrogram obtained by UPGMA, the cophenetic correlation coefficient (CCC) was calculated (SOKAL; ROHLF, 1962) with 1000 simulations and analyzed by the " $t$ " test. After grouping, the intra and inter distances were computed and the means of each characteristic for the genotypes of each group estimated. The relative contribution of traits to divergence was obtained by the method of Singh (1981). All statistical analyses were performed using software GENES (CRUZ, 2008).

\section{RESULTS AND DISCUSSION}

Analysis of variance showed significant differences for all traits, evidencing the existence of variability and the possibility of selection among the genotypes studied. 
By the Tocher method it was possible to cluster five groups (Table 1), with the largest number of genotypes in group I. The greatest distance between the minima was 72.42 , for genotype 46 allocated in group V, with some characteristics that made it the most divergent of all (fruit and peduncle length, canopy diameter, fruit and peduncle width and 100- seed weight) (Table 2). It is also noteworthy that although most of the genotypes were assigned to group I, the six genotypes in the groups II, III, IV, and V have important traits that are interesting with a view to the choice of parents for a breeding program with specific breeding objectives, e.g.: plant height, canopy diameter, cycle, fruit size, branching, and number of seeds per fruit.

Table 1 - Grouping by the Tocher optimization method using 137 genotypes of Capsicum chinense Jacq., evaluated for 20 morphological descriptors.

\begin{tabular}{|c|c|}
\hline Groups & Genotypes \\
\hline I & 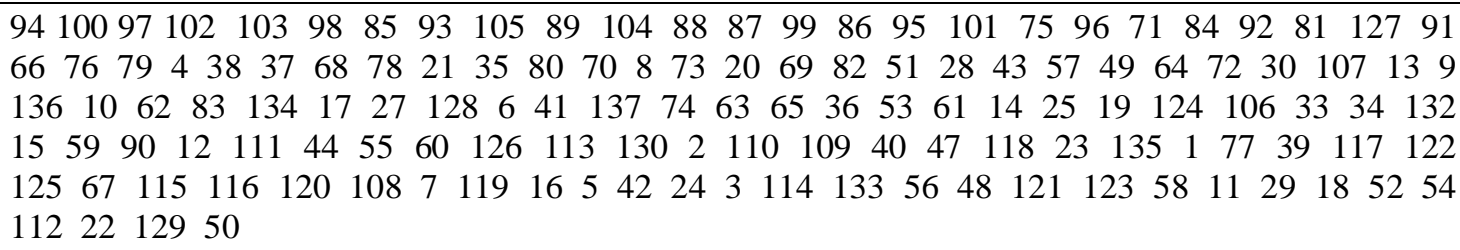 \\
\hline II & 313226 \\
\hline III & 45 \\
\hline IV & 131 \\
\hline V & 46 \\
\hline
\end{tabular}

Table 2 - Averages for the descriptors in the groups formed by the Tocher optimization method.

\begin{tabular}{crrrrr}
\hline & \multicolumn{5}{c}{ Tocher groups } \\
\cline { 2 - 5 } Variables & \multicolumn{1}{c}{$\mathrm{I}$} & \multicolumn{1}{c}{ II } & \multicolumn{1}{c}{ III } & \multicolumn{1}{c}{ IV } \\
\hline Plant height $(\mathrm{cm})$ & $89.00 \mathrm{a}$ & $63.96 \mathrm{a}$ & $97.25 \mathrm{a}$ & $128.25 \mathrm{a}$ & $91.75 \mathrm{a}$ \\
Height of the 1st bifurcation $(\mathrm{cm})$ & $29.59 \mathrm{a}$ & $19.67 \mathrm{a}$ & $27.38 \mathrm{a}$ & $70.50 \mathrm{a}$ & $48.75 \mathrm{a}$ \\
Fruit length $(\mathrm{mm})$ & $23.05 \mathrm{~d}$ & $53.17 \mathrm{a}$ & $30.18 \mathrm{c}$ & $12.62 \mathrm{e}$ & $43.04 \mathrm{~b}$ \\
Peduncle length $(\mathrm{mm})$ & $22.54 \mathrm{a}$ & $23.82 \mathrm{a}$ & $24.97 \mathrm{a}$ & $24.13 \mathrm{a}$ & $35.45 \mathrm{a}$ \\
Canopy diameter $(\mathrm{cm})$ & $111.54 \mathrm{a}$ & $112.00 \mathrm{a}$ & $122.00 \mathrm{a}$ & $94.25 \mathrm{a}$ & $50.13 \mathrm{a}$ \\
Corolla length $(\mathrm{mm})$ & $11.51 \mathrm{a}$ & $11.91 \mathrm{a}$ & $14.47 \mathrm{a}$ & $11.51 \mathrm{a}$ & $12.46 \mathrm{a}$ \\
Leaf length $(\mathrm{mm})$ & $70.26 \mathrm{a}$ & $77.64 \mathrm{a}$ & $88.35 \mathrm{a}$ & $98.56 \mathrm{a}$ & $91.48 \mathrm{a}$ \\
Stem diameter $(\mathrm{mm})$ & $10.77 \mathrm{a}$ & $11.39 \mathrm{a}$ & $14.76 \mathrm{a}$ & $10.74 \mathrm{a}$ & $12.03 \mathrm{a}$ \\
Fruit wall thickness $(\mathrm{mm})$ & $1.69 \mathrm{a}$ & $1.65 \mathrm{a}$ & $2.50 \mathrm{a}$ & $1.87 \mathrm{a}$ & $1.99 \mathrm{a}$ \\
Fruit width $(\mathrm{mm})$ & $13.71 \mathrm{a}$ & $13.61 \mathrm{a}$ & $20.44 \mathrm{a}$ & $15.71 \mathrm{a}$ & $28.10 \mathrm{a}$ \\
Peduncle width (mm) & $1.43 \mathrm{c}$ & $1.59 \mathrm{~b}$ & $1.37 \mathrm{c}$ & $1.56 \mathrm{~b}$ & $1.90 \mathrm{a}$ \\
Leaf width (mm) & $31.14 \mathrm{a}$ & $29.44 \mathrm{a}$ & $33.04 \mathrm{a}$ & $47.74 \mathrm{a}$ & $41.71 \mathrm{a}$ \\
10-fruit weight $(\mathrm{g})$ & $14.15 \mathrm{a}$ & $29.54 \mathrm{a}$ & $56.01 \mathrm{a}$ & $13.76 \mathrm{a}$ & $69.09 \mathrm{a}$ \\
100-grain weight $(\mathrm{g})$ & $0.60 \mathrm{a}$ & $0.63 \mathrm{a}$ & $0.82 \mathrm{a}$ & $0.54 \mathrm{a}$ & $0.92 \mathrm{a}$ \\
Number of locules & $2.83 \mathrm{a}$ & $3.22 \mathrm{a}$ & $3.38 \mathrm{a}$ & $2.83 \mathrm{a}$ & $3.00 \mathrm{a}$ \\
Number of days until fruit set & $108.93 \mathrm{a}$ & $97.17 \mathrm{a}$ & $120.00 \mathrm{a}$ & $123.00 \mathrm{a}$ & $134.25 \mathrm{a}$ \\
Number of branches & $4.33 \mathrm{a}$ & $14.08 \mathrm{a}$ & $1.00 \mathrm{a}$ & $0.00 \mathrm{a}$ & $2.25 \mathrm{a}$ \\
Number of days until fruit set & $156.35 \mathrm{a}$ & $152.33 \mathrm{a}$ & $168.75 \mathrm{a}$ & $180.50 \mathrm{a}$ & $173.67 \mathrm{a}$ \\
Number of seeds per fruit & $22.61 \mathrm{a}$ & $28.35 \mathrm{a}$ & $35.47 \mathrm{a}$ & $9.43 \mathrm{a}$ & $29.00 \mathrm{a}$ \\
Seed size (mm) & $3.59 \mathrm{a}$ & $3.62 \mathrm{a}$ & $4.24 \mathrm{a}$ & $3.58 \mathrm{a}$ & $4.24 \mathrm{a}$ \\
\hline
\end{tabular}

Means followed by the same letter in the horizontal do not differ among themselves by the Tukey test at the level of $5 \%$ probability. 
Of the genotypes studied, $96 \%$ were assigned to group I, by the Tocher optimization method. However, the genotypes of this group were very heterogeneous. The reason was, as previously reported, the large genetic divergence between genotype 46 and the others, since, as reported by Cruz and Carneiro (2006) the criterion for belonging to a group by this technique is based on a pre-set value; in this work, the greatest distance between the minima was used. Therefore, if a plant is very divergent, the minimum distance from it is high and it is used as intra-group measure. Consequently, genetically different plants can be grouped in the same group and, as in this study, a regrouping of Group I may be indicated for a better discrimination of the genotypes of this group.

It was observed (Table 3) that the intragroup distances were shortest, as determined by the grouping method. It was also observed that the largest distances between groups were between II and V, indicating that these groups are most divergent from the others. As reported by Miranda; Cruz and Costa (1988), the genetic distance of parents, based on a satisfactory set of traits, is potentially promising for an efficient and economic identification of advantageous hybrid combinations, which may contribute to the choice of the parents to be intercrossed to increase segregation and have a more successful breeding program.

Table 3 - Intra-and inter-group averages of Mahalanobis' distance in Capsicum chinense Jacq., grouped by the Tocher method.

\begin{tabular}{ccrrrr}
\hline Group & I & \multicolumn{1}{c}{ II } & \multicolumn{1}{c}{ III } & \multicolumn{1}{c}{ IV } & \multicolumn{1}{c}{ V } \\
\hline I & 40.8 & 105.3 & 91.9 & 73.2 & 167.4 \\
II & & 60.9 & 143.5 & 194.2 & 195.3 \\
III & & & 0.0 & 122.4 & 95.1 \\
IV & & & & 0.0 & 156.7 \\
V & & & & & 0.0 \\
\hline
\end{tabular}

By the UPGMA clustering method, it was possible to observe the distribution of genotypes in a larger number of groups, compared to the Tocher method. This was due to the different algorithms used in the methods. Eleven groups were formed by the UPGMA method, considering the cutting on the coordinate axis at a relative distance of $24 \%$ between the genotypes (Figure 1). This cutoff, although subjective, was determined from the observation of the point of high variation level, considered a threshold of the number of genotypes in the group (CRUZ; CARNEIRO, 2006). Sudré et al. (2005) used a cutoff at a distance of $30 \%$ in the dendrogram, and emphasized the importance of using more than one clustering method.

For the grouping of the genotypes considered most divergent $(26,31,32,45,46$, and 131) coincidence was observed between the groups formed by the Tocher and by the UPGMA analysis. This fact shows the great influence of these genotypes on determining the distance established by the Tocher method for the inclusion of a plant in the same group.

The cophenetic correlation coefficient for the hierarchical clustering method UPGMA was 0.797 and significant at $1 \%$ probability. This coefficient can be used to assess the consistency of the grouping pattern by hierarchical clustering methods, where values close to unity indicate better representativeness (CRUZ; CARNEIRO, 2006). Therefore, the dendrogram expressed a strong relation with the original data.

The intra and inter-group distances for the hierarchical clustering method UPGMA. (Table 4) show the shortest mean distances between the groups $\mathrm{V}$ and $\mathrm{X}(0.1)$, II and VI (0.3) and I and III ( 0.7), showing that the intercrossing of plants of these pairs of groups is not indicated when the heterotic effect is the target. The average distances were highest between the group pairs VI - XI (153.5), II - XI (153.2), and IV- XI (146.7). Therefore, these group pairs are considered the most divergent, with differences for most traits (see Table 4). Intercrossing of the genotypes of these groups is indicated to increase the variability and the possibility of expression of the heterotic effect. Genotype 46 of group V (Tocher) and of group XI (UPGMA) was the most divergent of all, as indicated by the greatest distances between groups (Table 3 and table 4), by both grouping methods.

Fruit-related traits are highly important for pepper breeding, since the consumer market determines the form of consumption and acceptance. Ripe, small and round fruits are preferentially consumed in the Northeast, and thin and elongated peppers in the Southeast (REIFSCHNEIDER, 2000). In this study, variability among the genotypes under study was verified for fruit-related variables such as length, width, 10-fruit weight, and fruit wall thickness, allowing the selection of parents for crosses with a view to the market demand. 


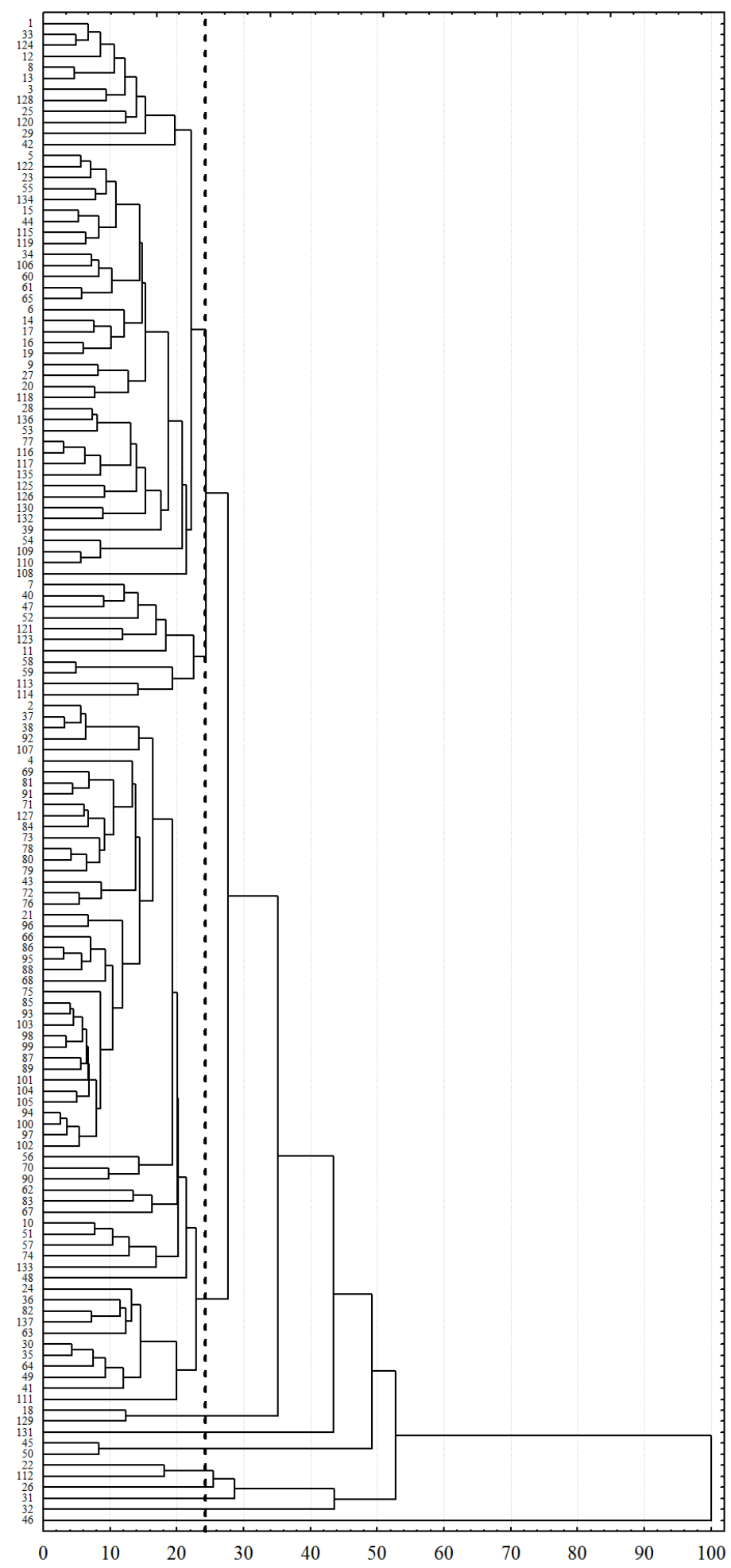

Figure 1 - UPGMA dendrogram of 137 genotypes of Capsicum chinense Jacq. using Mahalanobis' distance for the studied variables.

Ciênc. agrotec., Lavras, v. 36, n. 5, p. 498-506, set./out., 2012 
Table 4 - Intra-and inter-group averages of Mahalanobis' distance in Capsicum chinense Jacq., clustered by the UPGMA method.

\begin{tabular}{cccrrrrrrrrr}
\hline Group & I & II & \multicolumn{1}{c}{ III } & \multicolumn{1}{c}{ IV } & \multicolumn{1}{c}{ V } & \multicolumn{1}{c}{ VI } & \multicolumn{1}{c}{ VII } & \multicolumn{1}{c}{ VIII } & \multicolumn{1}{c}{ IX } & \multicolumn{1}{c}{ X } & \multicolumn{1}{c}{ XI } \\
\hline I & 16.5 & 24.5 & 0.7 & 18.0 & 33.9 & 24.8 & 8.6 & 3.9 & 9.1 & 34.0 & 128.7 \\
II & & 11.9 & 23.8 & 6.5 & 58.4 & 0.3 & 15.9 & 28.4 & 33.6 & 58.5 & 153.2 \\
III & & & 18.9 & 17.3 & 34.6 & 24.1 & 7.9 & 4.6 & 9.8 & 34.7 & 129.4 \\
IV & & & & 20.7 & 51.9 & 6.8 & 9.4 & 21.9 & 27.1 & 52.0 & 146.7 \\
V & & & & & 0.0 & 58.7 & 42.5 & 30.0 & 24.8 & 0.1 & 94.8 \\
VI & & & & & 14.0 & 16.2 & 28.7 & 33.9 & 58.8 & 153.5 \\
VII & & & & & & 30.3 & 12.5 & 17.7 & 42.6 & 137.3 \\
VIII & & & & & & & 0.0 & 5.2 & 30.1 & 124.8 \\
IX & & & & & & & & 0.0 & 24.9 & 119.6 \\
X & & & & & & & & & 0.0 & 94.7 \\
XI & & & & & & & & & & 0.0 \\
\hline
\end{tabular}

Plant height and cycle are highly important in crop management, making group VIII, IX and X (UPGMA) interesting, for the traits of genotypes 26,31 e 32 which could be used in breeding programs for short and early plants. The averages of the variables of the other groups are shown in table 5 .

The two clustering methods were partially concordant in the separation of genotypes, allowing an improvement of group I, discriminated by Tocher, by the UPGMA method, and to keep the most divergent genotypes in separate groups.

By the method of Singh (1981), used to evaluate the relative importance of the 20 descriptors, it was found that 10 descriptors contributed with $97.07 \%$ to the total variation. The characteristics that most contributed by the method to total variation was the number of days to flowering $(22.26 \%)$, followed by plant height $(19.44 \%)$, leaf length (12.18\%), diameter canopy (12.10\%), number of seeds per fruit (9.54\%), 10-fruit weight (6.41\%) and height of the first bifurcation (6.41\%). Number of days to flowering, plant height and canopy diameter are traits associated with the early reproductive stage or plant size, and therefore have a high agronomic value. The other traits contributed little to the total divergence, so in future studies they may serve as a reference in the choice of descriptors that should be measured.

These results disagree with results of Bento et al. (2007), who found that the two variables that contributed most to genetic diversity were number of fruits per plant (45.99\%)and number of seeds per fruit (21.88\%), and of Sudré et al. (2005), who identified fruit length $(32 \%)$ and fruit diameter $(32 \%)$ as the most divergent. However, both studies addressed the genus Capsicum spp, not only the species Capsicum chinense Jacq, as in this work. In a study of Ferrão et al. (2011) on C. baccatum, the trait that contributed most to the differentiation was fruit length $(40.9 \%)$, and the value was lowest $(0.5 \%)$ for the number of locules. 


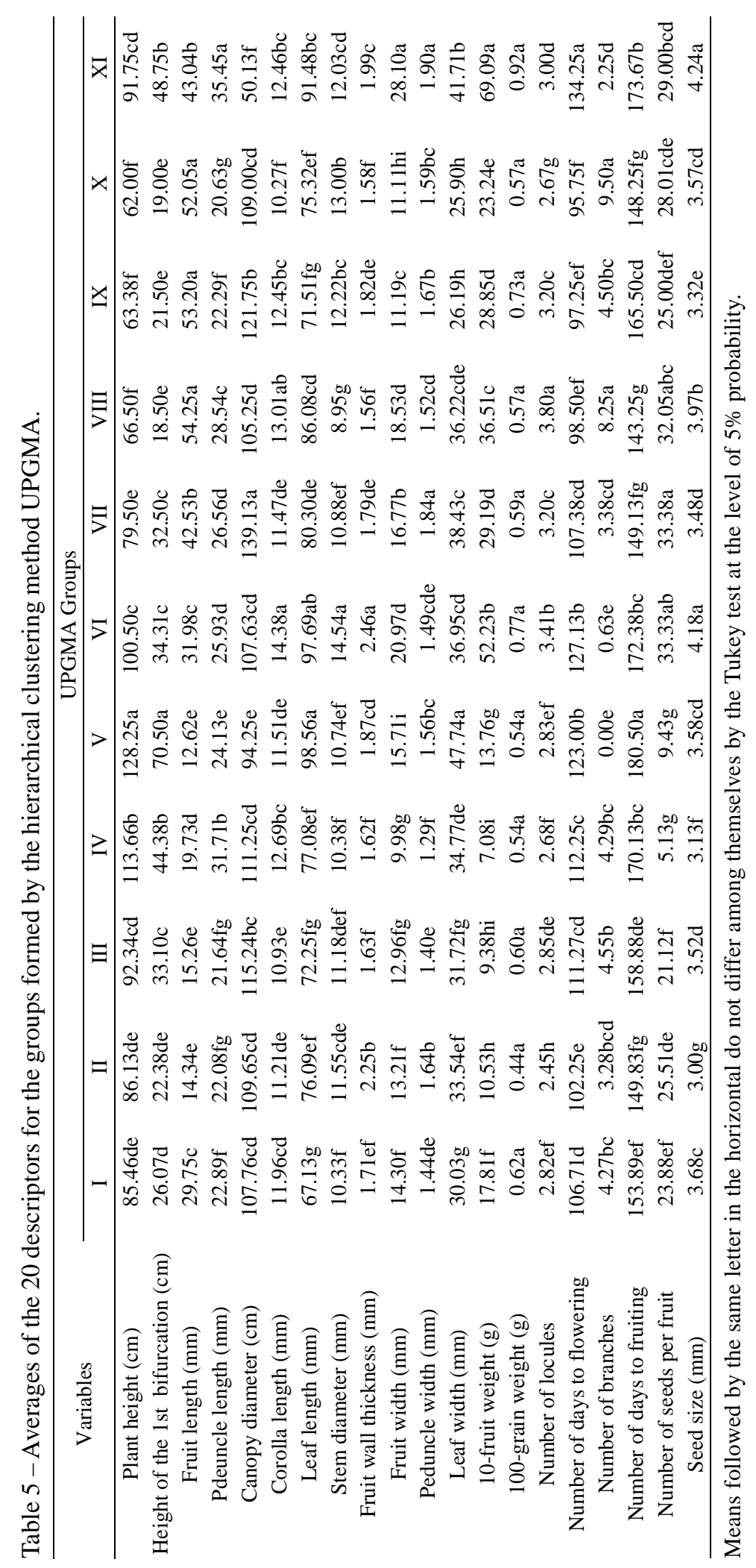

Ciênc. agrotec., Lavras, v. 36, n. 5, p. 498-506, set./out., 2012 


\section{CONCLUSIONS}

There is genetic divergence among the accessions of $C$. chinense for all the descriptors, indicating a potential use in breeding programs. The traits that contributed most to the divergence are number of days to flowering, plant height, leaf length, and canopy diameter.

The groups formed by Tocher and UPGMA methods are partially coincident in the separation of the genotypes, improving the discrimination by Tocher of Group I with UPGMA.

The most promising crosses between genotypes of groups clustered by the Tocher optimization method were II x V, II x IV, and V x I, and by UPGMA crosses between VI x XI, II x XI, and IV x XI.

\section{ACKNOWLEDGEMENTS}

The authors are indebted to $\mathrm{CNPq}$ for funding this research project.

\section{REFERENCES}

BENIN, G. et al. Identificação da dissimilaridade genética entre genótipos de feijoeiro comum (Phaseolus vulgaris L.) do grupo preto. Revista Brasileira de Agrociência, Pelotas, v.8, n.3, p.179-184, set./dez. 2002.

BENTO, C. S. et al. Descritores qualitativos e multicategóricos na estimativa da variabilidade fenotípica entre acessos de pimentas. Scientia Agraria, Curitiba, v.8, n.2, p.149-156, abr./jun. 2007.

CARVALHO, S.I.C. et al. Catálogo de germoplasma de pimentas e pimentões (Capsicum spp.) da Embrapa Hortaliças. Brasília: Embrapa Hortaliças, 2003. 49p.

CARVAlHO, S.I.C. de et al. (eds.). Pimentas Capsicum. Brasília: Embrapa Hortaliças, 2008. p.39-54.

CRUZ, C.D. Programa Genes: Diversidade genética. Viçosa: UFV, 2008. 278p.

CRUZ, C.D.; CARNEIRO, P.C.S. Modelos biométricos aplicados ao melhoramento genético. Viçosa: UFV, 2006. $585 \mathrm{p}$.

FERRÃO, L.F.V. et al. Divergência genética entre genótipos de pimenta com base em caracteres morfoagronômicos. Horticultura Brasileira, Brasília, v.29, n.3, p.354-358, jul./set. 2011.
FILGUEIRA, F.A.R. Novo manual de olericultura: agrotecnologia moderna na produção e comercialização de hortaliças. Viçosa: UFV, 2000. 402p.

\section{INTERNATIONALPLANT GENETIC RESOURCES INSTITUTE-IPGRI. Descriptors for Capsicum (Capsicum spp.) Rome, 1995. 51p.}

LANNES, S.D. et al. Growth and quality of Brazilian accessions of Capsicum chinense fruits. Scientia Horticulturae, Amsterdã, v.112, n.3, p.266-270, abr. 2007.

MIRANDA, J.E.C. de; CRUZ, C.D.; COSTA, C.P. da. Predição do comportamento de híbridos de pimentão (Capsicum annuum L.) pela divergência genética dos progenitores. Revista Brasileira de Genética, Ribeirão Preto, v.11, n.4, p.929-937, dez. 1988.

MONTEIRO, E.R. et al. Diversidade genética entre acessos de espécies cultivadas de pimentas. Ciência Rural, Santa Maria, v.40, n.2, p.288-293, fev. 2010.

MOURA, M.C.C.L. et al. Algoritmo de Gower na estimativa da divergência genética em germoplasma de pimenta. Horticultura Brasileira, Brasília, v.28, n.2, p.155-161, abr./jun. 2010.

RAO, R.C. Advanced statistical methods in biometrics research. New York: John Wiley, 1952. 390p.

REIFSCHNEIDER, F.J.B. Capsicum: Pimentas e pimentões no Brasil. Brasília: Embrapa Hortaliças, 2000. 113p.

REGO, E.R. do. et al. Genetic diversity analysis of peppers: a comparison of discarding variable methods. Crop Breeding and Applied Biotechnology, Viçosa, v.3, n.1,p.19-26, abr./jun. 2003.

SINGH, D. The relative importance of characters affecting genetic divergence. Indian Journal of Genetics and Plant Breeding, New Delhi, v.41, n.2, p.237-245, may. 1981.

SNEATH, P.H.A.; SOKAL, R.R. Numerical Taxonomy: The principles and practice of numerical classification. São Francisco: W.H. Freeman, v. 215, n.6, p.106-116, dec, 1973.

SOKAL, R.R.; ROHLF, F.J. The comparison of dendrograms by objective methods. Taxon, Berlin, v.11, n.2, p.33-40, fev. 1962. 
SOUSA, J.A. de; MALUF, W.R. Estimação de heterose em pimenta (Capsicum chinense Jacq.). Ciência e Agrotecnologia, Lavras, v.24, n.3, p.623-631, jul./set. 2000.
SUDRÉ, C.P. et al. Divergência genética entre acessos de pimenta e pimentão utilizando técnicas multivariadas. Horticultura Brasileira, Brasília, v.23, n.1, p.22-27, jan./ mar. 2005.

Ciênc. agrotec., Lavras, v. 36, n. 5, p. 498-506, set./out., 2012 